\title{
Students' Perception on E-Portfolio for Assessing Translation Skill
}

\author{
Witri Handayani1 $^{1)}$, Yenni Rozimela ${ }^{2)}$, Haris Effendi Thahar ${ }^{3)}$ \\ ${ }^{1)}$ Politeknik Negeri Padang/IKB UNP, ${ }^{2), 3}$ Universitas Negeri Padang \\ Email: wietripnp@gmail.com ${ }^{1}$, yennirozi@gmail.com ${ }^{2}, \underline{\text { harrispadang@gmail.com }}^{3}$
}

\begin{abstract}
Translation is actually the skill which involve students' active contribution in the assessing process. Meanwhile, e-portfolio regards as one of the method to achieve students' active contribution in assessing their own translation works since it not only functions to collect the works electronically but can also function to show the sequence of works improvement. The aim of this study is to investigate students' perception on e-portfolio for assessing their translation skill. It was also intended to discover application preference to apply the e-portfolio method of assessment. The participants of the study are 49 English Department students enrolled in the third year. The data was collected by using questionnaire in the form of closed and open questionnaires. The results indicate that the participants generally prefer to be evaluated by the e-portfolio assessment. Most of them believed that e-portfolio assessment improved their translation quality and enhanced their motivation and the application they chose to apply the e-portfolio is the free application which can be accessed anywhere.
\end{abstract}

Keywords: students' perception, e-portfolio, assessing translation.

\section{Introduction}

Translation is the skill which requires much competence application in the process. Some people learned translation skill autodidactly while some others choose to learn it from formal institution which offer translation study. For the students of translation, better acquire of the translation competence is achieved through active contribution not only in the learning process but in the assessing process as well. Therefore, appropriate assessing model for translation is needed as it very much influences the result of translation acquisition since assessment functions as the process of assigning and level up learners capability which should be conducted as one of learning control for learning effectiveness measurement (Hidayat, 2013).

Furthermore, choosing the appropriate method for assessing the students translation competence is another callenging task due to several factors: (1) there is no fixed standard for assessing the translation quality due to impracticality and reliability (Tanuwijaya et al., 2016), (2) practically it conducted in a subjective, indicipline/ ad hoc fashion (Melis \& Albir, 2001), (3) translation evaluation should cope three areas of translation:the evaluation of published translations, the evaluation of professional translators'work and evaluation in translation teaching (Malis as cited in Malis \& Albir, 2001), and (4) to achieve better result, learner freedom space for doing experiments and applying their own hypotheses about language without worries their overall competence is being analysed during the process should be provided (Brown \& Abeywickrama, 2010). Due to all of these phenomenon, e-portfolio is regarded as one of the solution to solve the translation assessment problems.

E-portfolio is the short term of electronic protfolio which function to organize the collection of works or products that depicted the owner self recording includes their activity, accomplishments and achievements (Aulia, Yulastri \& Sari, 2014; Venn in Valenzuela, 2002) electronically. The e-portfolio 
allows the students to include their multimedia format works complete with their personal account of their most meaningful learning experiences and other materials to support their learning process (Polo \& Valera, 2011). In addition, the utilization of e-portfolio develops students' performance because they have to revise the feedback they got (Insai, 2013), in the same time, it develops both students competence in translation and the other skills, such as decision making, problem solving, critical thinking, selfmonitoring and self-assessing (Johnson, 2003; Campos, 2004; Haiyan, 2006; Rico, 2010).

Despite all of positive feedback about e-portfolio as the method for assessing translation skill, there are some factors which influence students' opinion in applying this e-portfolio to assess their translation learning process. In English Department of Politeknik Negeri Padang where this study is conducted, different result in the same class in mutual environment can be obtained from the application of this eportfolio.Therefore, this study is aimed to: (1) investigate students' perception on e-portfolio for assessing translation skill which will be used as the based for further study in the same field, (2) whether the students know the function of assessment in increasing their translation skill, (3) whether this e-portfolio can gain students motivation in producing better translation result and (4) what kind of application that they choose as the platform for their e-portfolio.

\section{Methods}

This study would discuss the perception of the students on e-portfolio for assessing translation skill in descriptive qualitative. The data would be obtained from the questionnaire in closed-ended form and open-ended form. The closed-ended form questionnaire is used as the main data to investigate the perception of the students, while the open-ended questionnaire is used to enrichen the analysis toward the result of the main data. The questionnaire consists of 22 questions; 16 closed-ended questions which used five level of likert scale (Strongly Agree, Agree, Undecided, Disagree and Strongly Disagree) and 6 open-ended questions. The participants are the third year English Department students of Politeknik Negeri Padang with the age range between 18-20 years old.They consist of 49 students who take diploma 3 (three) and have been learned translation subject for two years.

\section{Result and Discussion}

The result of the questionnaire shows the preference of the students in surprising number of tendencies. The complete analyses would be presented below.

\section{The Students Know The Function of Assessment in Increasing Their Translation Skill}

The data shows positive agreement about the subject mater. 57,1\% of the students state that they are agree with the statement that the students need to involve on the assessment process to master translation skill, $21,4 \%$ of the students are in the position of strongly agree and the same percentage of $7,1 \%$ for the undecided, disagree and strongly disagree. There are several reasons they gave to support their answer, such as:

\begin{tabular}{|c|c|}
\hline No. & Reasons for Agreement \\
\hline 1 & $\begin{array}{l}\text { I agree, because with this assessment process we students can find out where } \\
\text { our weaknesses and mistakes are, so that we can improve and improve our } \\
\text { abilities in the future. }\end{array}$ \\
\hline 2 & I think by knowing the value, the efforts we do will increase even more. \\
\hline 3 & The assessment given as a medium for students to practice and train themselve \\
\hline 4 & $\begin{array}{l}\text { I absolutely agree, by doing the assessment in every task, we can find out the } \\
\text { weaknesses and strengths that we have. Through assessment, we can also } \\
\text { improve and develop our abilities again after knowing the mistakes of the }\end{array}$ \\
\hline
\end{tabular}




\begin{tabular}{ll}
\hline 5 & $\begin{array}{l}\text { previous mistakes. } \\
\text { The process of assessment aims to make skill changes, or better at doing } \\
\text { further translation } \\
\text { To master translation skills, it is undeniable the need to involve in every } \\
\text { aspects of that certain skill }\end{array}$ \\
7 & $\begin{array}{l}\text { Because in translation, the results will affect the value of the translation results. } \\
\text { Because we need strongly translate of the message. We practice everytime,do } \\
\text { assesment. So we can improve our translate skill. }\end{array}$ \\
\hline
\end{tabular}

From the table above, it can clearly be seen that the students are aware of the function of assessment in their translation study and they agree that by knowing the assessment process, the students can find out their weaknesses and mistake to improve their ability of translation in the future. They also agree that it is needed to involve in every aspects of translation process include the assessment process to master translation skill better and the process of assessment aims to make translation skill changes. This statement is supported by Bloxham \& Boyd (2007) that assessment may affect the behaviour of the students and shape more than the teaching process can convey alone. They also know that to accomplish better result in mastering translation skill, lots of practice is needed and the mastery of several other skills which support the translation skill such as reading, writing and grammar skill is also needed.

\section{Students' Perception on E-Portfolio for Assessing Translation Skill}

There are three statement of agreement which address to find out students' perception on e-portfio for assessing translation skill, they are (1) e-portfolio improves their translation skill, (2) that their translation awareness improves by revising the correction from their lecturer, (3) that they got better result of translation by doing editing and revising their own translation result and (4) I like my translation result to be assessed by e-portfolio. The data showsthat $40 \%$ of the students chose undecided for the statement number (1), 26.7\% are strongly agree and $20 \%$ are agree with the statement, while $13.3 \%$ are stated that they are strongly disagree with the statement.However, $46.7 \%$ students are strongly agree and $20 \%$ are agree with the statement number (2). Then, $40 \%$ students are strongly agree and $13.3 \%$ are agree with the statement number (3). In addition, 33.3\% students are strongly agree with the (4) statement and another $33.3 \%$ agree with it.

From the data description above can be analyzed that actually the students have agreeed that the process of self-editing and revision, and the process of revising the correction from the lecturerhave improved their translation awareness and lead them to produce better translation result. This result can also be proved by their statement on open-ended questionnaire which can be seen in table 2 below. Furthermore, from the statement number (4) $66.6 \%$ of them give positive respond toward the use of eportfolio assessment.However, it seems that only $46.7 \%$ of them realized that the process they did in the translation study which involve editing-correcting-revising are part of e-portfolio assessment in their learning process.

Table 2. Some Students Reason to Support Their Agreement about Students' Perception

\begin{tabular}{cl}
\hline No. & \multicolumn{1}{c}{ Reasons for Agreement } \\
\hline 1 & $\begin{array}{l}\text { Reading your translation work a couple of times will help you find errors and } \\
\text { fix them. }\end{array}$ \\
2 & $\begin{array}{l}\text { Of course, by editing and revising our own translations, we can certainly be } \\
\text { better for the next assignment, because it is very unlikely that we will repeat } \\
\text { the same mistakes. }\end{array}$ \\
3 & That's right, by revising and editing our own translations it will train our skills \\
\hline
\end{tabular}




\begin{tabular}{l}
\hline in translation. \\
4 We need to do editing to correct and make sure that our translation is correct. \\
5 I do strongly agree based on my experience, editing make improve my \\
translation skill, before know translation i didn't use very well the right \\
punctuation, conjunction, etc. By editing and revising now clearly I can pay \\
attention make it into comprehensive and grammatical. \\
6 Of course. After editing and revising, the result should be better. \\
7 As far as I can concern that editing and revision by my own self it's not \\
enough, I need other people to give comment and advise to make my \\
translation more better. \\
Maybe it takes work such as correcting fellow friends, if correcting your own \\
work then there will be justification as long as it is justified. In my opinion, the \\
results of corrections from friends can make us study better. \\
Practice,revising your own translation result can help you to undestand much \\
about the translation proces. You can find when you make a mistake and can \\
fix it. If you did not revising your translation result you wil never know where \\
you are make mistake and cant fix it. That is no improve of your translation \\
study. \\
Because by editing and revising, we can fix the wrong things before.
\end{tabular}

From the statement above, it is clear that the students are mostly agree that e-portfolio assessment can improve their translation result. However, they chose different method in applying the e-portfolio; some of them chose to do self-assessment, another chose to have peer correction with their friends, while some others chose to be corrected by their lecturer directly.

Based on this positive reaction, the application of e-portfolio assessment in translation is the right choice and this result agrees with Insai (2013) opinion that the classroom activity should integrate the application of learning, teaching and assessment, and portfolio utilization can be one possible alternative to bridge the gaps in translation study as it is a part of learninig process and assessment schemes.

\section{E-Portfolio Can Gain Students Motivation in Producing Better Translation Result}

The data indicates that $33.3 \%$ of the students agree that it is easy to learn their mistake after being assessed by using e-porfilio and $26.7 \%$ are strongly agree. Then, about the increasing of motivation, $33.3 \%$ are strongly agree that their motivation increases after they learn from their e-portfolio and $26.7 \%$ of them are agree.

This number of percentation shows positive reaction from the students. More than half number of participants state that their motivation increased after their translation works being assessed by e-portfolio because it made them easy to recognize and revise their mistake, and learn to avoid making the same mistake. This is analogous with Fitri's (2015) research findings which described that learners believe that portfolio is motivating and appealing beacuse it enables them to be autonomous.

\section{Kind of Application that They Choose as The Platform for Their E-Portfolio}

Students strongly agree in $40 \%$ that e-portfolio is more practical than traditional portfolio, and $20 \%$ of them state their agreement as well. Meanwhile for the platform of e-portfolio itself, $33.3 \%$ strongly agree to use free application for their e-portfolio and $26.7 \%$ of them agree.

This result indicates that the students are mostly agree that e-portfolio is more practical than the traditional one as the development of technology also provide the oportunity to use more digital tools for learning. However, the students have a tendency to use free access application as the platform for their e- 
portfolio because it can be easily accessed anywhere at anytime, depend on the need and occation of the students. In addition, the students also state that they would like to share their e-portfolio with the purpose for other students to also learn from their mistake and avoid repeating the same mistake.

\section{Conclusion}

Translation is a complex skillwhich requires serious engagement in the acquisition process. Several findings can be concluded from this study. First, the students mostly agree that the use of assessment on their translation study is needed and they should participate actively during the process of assessment. Second, students' perception on the e-portfolio for translation assessment got more positive reaction. They have conceded that the process of editing-correcting-revising which parts of e-portfolio has increased their sensitiveness in producing better translation result. Third, as their mistake can easily be understood by tracing back on their e-portfolio, the students find that their motivation has increased in having better translation result. Last, recent technology provides the opportunity for the students to access many digital websites and platforms, yet the students choose to utilize free access platform for their eportfolio for practical reason, as it is can be accessed freely anytime and anywhere.

\section{Acknowledgments}

The author currently teaches in English Department, Politeknik Negeri Padang and, at the same time, studies doctoral program in Ilmu Keguruan Bahasa, Universitas Negeri Padang. This study is part of disertasion of Doctoral program at Ilmu Keguruan Bahasa, Universitas Negeri Padang whose supervised by Professor Yeni Rozimela, Ph.D and Professor Dr. Harris Effendi Thahar.

\section{References}

Aulia, D., Yulastri, D., \& Sari, I. (2014). The use of portfolio to improve translation ability of English department students in State Polytechnic of Padang. Proceedings of ISELT FBS Universitas Negeri Padang, 2, 100-106.

Bloxham, S., \& Boyd, P. (2007). Developing effective Assessment in Higher education: A practical guide. London: Open University Press.

Brown, H. D., \& Abeywickrama, P. (2010). Language assessment: Principles and classroom practices. California: Pearson Education, Inc.

Campos, Ó. R. (2004). El portafolio y la evaluación del proceso de traducción. Letras, 1(36), 27-64. http://45.162.204.56/ojs3/index.php/letras/article/view/3616.

Fithri, E. (2015). The application of portfolios to asses progress in writing EFL students at secondary school in Banda Aceh. Studies in English Language and Education, 2(1).

Haiyan, L. (2006). Cultivating translator competence: Teaching and testing. Translation Journal, 10(3).

Hidayat, M. T. (2013). Self-, peer-and teacher-assessment in translation course. pp. 1-13.

Insai, S. (2013). Learning portfolios in translation classrooms. Arab World English Journal, 4.

Johnson, J. E. (2003). Learning through portfolios. Beyond the Ivory Tower: Rethinking translation pedagogy, 12, 97-116. Amsterdam/Philadelphia: John Benjamin Publishing Company 
Melis, N. M. \& Albir, A. H. (2001). Assessment in translation studies: Research needs. Meta: journal des traducteurs/Meta: Translators' Journal, 46(2), 272-287.

Polo, F. J. F., \& Varela, M. C. (2011). Learning translation through the use of portfolios: description of an experience. @ tic. revista d'innovació educativa, (7), 44-51.

Rico, C. (2010). Translator training in the European Higher Education Area: Curriculum design for the Bologna Process. A case study. The interpreter and translator trainer, 4(1), 89-114.

Tanuwijaya, M., Nugroho, A. C., Ahdi, P., \& Dewi, N. (2016). An alternative assessment model to improve a translated text from Indonesian into English. Indonesian Journal of English Language Studies (IJELS), 2(1), 14.

Valenzuela, J. S. (2002). Defining portfolio assessment. US: The University of New Mexico. 